INTERNATIONAL JOURNAL OF RESEARCHES IN BIOSCIENCES, AGRICULTURE \& TECHNOLOGY (C) VISHWASHANTI MULTIPURPOSE SOCIETY (Global Peace Multipurpose Society) R. No. MH-659/13(N) www.vmsindia.org

\title{
EVALUATION OF PRESENT LIMNOLOGICAL STATUS OF NAVARGAON LAKE IN MAREGAON TALUKA, DISTRICT-YAVATMAL (M.S) INDIA
}

\section{${ }^{1}$ Waware S.K. and ${ }^{2}$ Kamdi R.R.}

${ }^{1}$ Sardar Patel Mahavidyalay, Chandrapur (M.S) India ${ }^{2}$ Anand Niketan College, Anandwan Warora, Chandrapur (M.S) India Email:kamdi.ramdas@gmail.com

\begin{abstract}
Navargaon lake was constructed as part of irrigation projects by Government of Maharashtra in the year 1997. Nearest city taco Lake is Maregaon and the Lake is situated in Maregaon Taluka of Yavatmal District of Maharashtra in India. It is built on and impounds Nirguda River. The study was conducted during Febuary 2016 to January 2017. The samples were analyzed at monthly intervals for a period of one year. Navargaon lake has greatest importance for humankind. The physico-chemical parameters are water temperature, electric conductivity, total dissolved solids, total hardness, total alkalinity, turbidity, $\mathrm{pH}$, dissolved oxygen, chlorides, COD , BOD, etc. The biological factors considered were macro-zoo benthos and plankton of the lake. Lake was highly productive as presence of various class and order of benthos, zooplankton and phytoplankton although there were no sign of problem like eutrophication. Biological studies indicate that lake water was fit for aquatic organism, such as fishes because of there were plenty of food.
\end{abstract}

Key words: - Physico-chemical, Macro-zoo benthos, Navargaon Lake

\section{Introduction:}

Biological production in any aquatic body gives direct correlation with its physicochemical status which can be used as trophic status and fisheries resources potential (Jhingran et al., 1965). Life in aquatic environment is largely governed by physico-chemical characteristics and their stability. The physico-chemical as well as the biological factor of lake have vital role in aquaculture and productivity of fishes. The quality of water determines the quality of fish to be produce in it. The physical factors are water temperature, water current and turbidity of water, whereas the chemical parameter of lake comprise $\mathrm{pH}$, dissolved oxygen, total alkalinity and total hardness of water. The biological factors considered were macro-zoo benthos and plankton of the lake. The seasonal changes in different physico-chemical parameters are responsible for annual variation and growth of biological factors viz.,macro-zoo benthos and plankton etc.

Tepe et al., (2005) found that the water quality attributes such as water temperature, light penetration, dissolved oxygen, total alkalinity and total hardness are the representative of the seasonal fluctuation . Ali et al., (2006) showed that the water quality of fresh water ecosystem undergoes complex changes due to all physico-chemical factors and water quality as a sequence disrupting the aquatic life. Hayat et al., (1996) and Jena et al., (1998) revealed that temperature and ecological conditions are responsible for the fluctuation of salt contents, which in turn influence the production, and growth of fish.

\section{Materials and Methods:}

The sampling was carried out in Navargaon lake at five different sites (Latitude: 20.0763283N and Longitude: 78.7675095E), monthly between Feb.2016 to Jan.2017 for one year. About 12 water sample were collected in each months. The physico-chemical factors are water temperature, water current, turbidity of water $\mathrm{pH}$, dissolved oxygen, total alkalinity and total hardness of water, whereas biological factors were macro-zoo benthos and plankton of the lake. Study of physicochemical factors was carried out by using standard methods (APHA, 2005. For the qualitative estimation safe water quality standards were use (Boyd and Tucker, 1998; Ali et al .,2006). Macro-zoo benthos collected from $1 \mathrm{~m}^{2}$ area of lake at the depth of $15 \mathrm{~cm}$. The plankton was sampled at each spot by filtering 100liters of water. Preservation was made on the spot in $4 \%$ formalin. The quantitative analysis of 
plankton was made with the help of Sedgwick-Rafter counting slide as suggested by Welch (1952).

\section{Result and Discussion: Water temperature}

The average water temperature of lake was found to be varying from $14.12^{\circ} \mathrm{C}$ to $21.58^{\circ} \mathrm{C}$ during Feb to August respectively. Thus, water of Navargaon lake is coldest in winter and hottest in monsoon. (Table- 1)

\section{Water velocity}

While calculating the velocity of water, we observed that the rate of water flow is fluctuated from a minimum value of $0.307 \mathrm{~m} / \mathrm{s}$ in Feb.to a maximum value of $0.899 \mathrm{~m} / \mathrm{s}$ in Aug. Thus the water current with a rate of $0.313 \mathrm{~m} / \mathrm{s}$ in winters to $0.849 \mathrm{~m} / \mathrm{s}$ in monsoon is useful for fish survive (Table 2).

\section{Turbidity}

It has been observed that the water is highly turbid during monsoon period (July-August) with a value of 92.9NTU. Thus is obvious because water becomes turbid due to the rainfall and flash flood. With an unusual variation water was found extremely less turbid during rest of the seasons with the minimum of 7.9 NTU in winter. (Table 3).

pH

$\mathrm{pH}$ fluctuation occur only within a narrow range. The $\mathrm{pH}$ of lake was found to be varying from 7.6 to 8.32 during July to December. Therefore, during monsoon the water is least basic and it seems more basic during winter (Table 4)

\section{Dissolved Oxygen}

In December, the oxygen content dissolved in water was found to be highest with the value of $10.72 \mathrm{mg} / 1$. The lake has less D. O. content in July with the value of $7.6 \mathrm{mg} / 1$. Thus the fish can endure water having the dissolved oxygen content from7.93mg/1 (during monsoon) to $10.57 \mathrm{mg} / 1$ (during winter). (Table 5).

\section{Total Alkalinity}

In our observation it has been observed that the lake water was alkaline and the magnitude was varying from $59.34 \mathrm{mg} / 1$ to $100.46 \mathrm{mg} / 1$ from Augustto February. Thus, the water of NavargaonLake is most alkaline during winter and then with a regular decrement is least alkaline during monsoon .(Table 6)

\section{Total Hardness}

The degree of hardness calculated in the lake water was lowest in July $(78.52 \mathrm{mg} / \mathrm{l})$ and highest in February (109.26 mg/1). The study summarized that the water in winter in highly hard, while least hard during monsoon.(Table 7).

\section{Macro-zoo benthic Density}

The number of Ephemeroptera (211 Units / $\mathrm{m}^{2}$ in December while $12 \mathrm{Unit} / \mathrm{m}^{2}$ in July), Trichopteran $\left(210 \mathrm{Unit} / \mathrm{m}^{2}\right.$ in December while $8 \mathrm{Unit} / \mathrm{m}^{2}$ in July), Dipteran (13 Units $/ \mathrm{m}^{2}$ in July while 145 Units $/ \mathrm{m}^{2}$ in February), Plecopteran nymphs (51Units $/ \mathrm{m}^{2}$ in January while 1 Units $/ \mathrm{m}^{2}$ in August), Coleopteran larvae (99 Units $/ \mathrm{m}^{2}$ in December while 9 Units $/ \mathrm{m}^{2}$ in July). Odonata larvae (130 Units $/ \mathrm{m}^{2}$ in December while 7 Units $/ \mathrm{m}^{2}$ in June). The average total macro-zoo benthos observed (815Units $/ \mathrm{m}^{2}$ in December while56 Units $/ \mathrm{m}^{2}$ in July) and (in winter season 646.33 Units $/ \mathrm{m}^{2}$ while during monsoon 114 Units $/ \mathrm{m}^{2}$ ). (Table 8).

\section{Plankton Diversity}

The total phytoplanktons were Chlorophyceae and Cyanophyceae (2925 Units/1 in January while 400 Units/1 in August). The total zooplaktons were Crustaceans and Rotifers (25Units/1 in August and 400 Units/1 in January ). The total plankton density vary (3110 Units/1 in January to 425 Units/1 in August.(table9).

In the present study, the water temperature of the lake was observed to be moderate throughout the year. This moderate water temperature is due to its spring-fed nature of origin. It is also supported by Odum (1971) that photoperiod was shorter in winter than summer which is directly related to temperature and hence water temperature is highest in June. The velocity of water current was observed to be fluctuated from a minimum of $0.307 \mathrm{~m} / \mathrm{s}$ (February) to a maximum of $0.899 \mathrm{~m} / \mathrm{s}$ (August). It is also obvious from our study that the average rate of water is highest in monsoon whereas lowest in winter.

In present study water was highly turbid during Monsoon (July-August) while very low during rest of the seasons with the minimum of 7.9 NTU in winter. These observations are also supported by Jhingran (1965) who reported that turbidity generally 
increased to a maximum value in monsoon due to the suspended solids in the flooded water whereas, during the post monsoon months the turbidity values were low but increased again during the summer months with the increase in tidal management and intensity .Upadhyay (1997) calculated the turbidity variation from 2 to $162 \mathrm{NTU}$.

$\mathrm{pH}$ is gradually increased from a minimum of 7.83 during monsoon to a maximum of 8.28 during summer. Similar variations in $\mathrm{pH}$ of the lake Khoh were recorded by Kumar et al.(2006) in Garhwal Himalayas. They concluded that winter maxima for $\mathrm{pH}$ might be due to algal growth and minima in monsoon might be due to influx of organic and inorganic ions in to the lake caused by flash flood.

In our study D O highest during winter whereas lowest during,Ali(1999) reported that the dissolved oxygen variation shows inverse relationship with water temperature variation. Bhatt et al (1984) also reported high $\mathrm{D} \mathrm{O}$ and low free $\mathrm{CO} 2$ concentration in winter.

In present study,the water of Navargaon lake was found to be most alkaline during winter and least during monsoon. Total hardness show minimum during monsoon to a maximum during winter.

Density of total macro-zoo benthos and total plankton populations were plenty in winter while rarely during monsoon. Detritus standing stock is the main reason for high density of benthos in winter and substratum stability too. Moderate temperature low gradient of velocity favors the growth of biotic communities. Similar study was carried out by Rautela et al.,(2006) who reported that the macro-zoo benthos had a maximum population during winter(325 Units $/ \mathrm{m}^{2}$ ) and the minimum (15 Units $/ \mathrm{m}^{2}$ ) during monsoon season.

\section{Conclusion:}

Briefly, present study concluded that physico-chemical parameters levels indicate the moderate quality of water, lake water of the study area was not polluted in respect to physico-chemical assessment. But biological studies indicate that lake water was fit for aquatic organism, such as fishes because of there were plenty of food in the form of benthos, zooplankton and phytoplankton.
Navargaon lake water was habitable for fishes and fit for development of aquaculture. There were no sign of problems like eutrophication. It is also concluded that the higher growth of macro-zoo benthos and planktons in the lake is favoured by low water temperature, low current velocity, moderate turbidity with high $\mathrm{D} O$, high alkalinity and high hardness during winters season.

\section{References:}

Assessment of water quality in the vicinity of municipal water pumping station of river Wainganga at Pawni, Distict. Bhandara (Maharashtra).

Bobdey A.D.Puranic P.G. Sawane A.P. Dhande R.S.\& Bhagat V.B. Bioscience Biotchnology Research Communications, Vol(3), No.(1)June 2010,(91-94).

Seasonal fluctuation of zooplankton in relation to industrial pollution in Irai River water, District Chandrapur,(M.S) India. Sawane A. P., Puranik P. G. \& Bobdey A. D. Environmental conservation journal (2010) Vol. 10(3)(81-85).

Seasonal distribution of zooplankton in Irai river, Dist. Chandrapur, Maharashtra Khinchi P. J., Dahegaonkar N. R., Telkhede P. M., and Sawane A. P. Journal of Science Information(Special Issue-3 for UGC Sponsored National Conference an "Current Status of Fresh Water Aquatic Biology and Water Conservation") Feb2012,(09-11).

Ichthyofaunal diversity of Wardha River and Nirguda river in selected stretch of Wani. Dist.Yavatmal(M.S.) India Khamankar D.B., Kamdi R.R. \& Sawane A.P.

Environment Conservation Journal (ISSN 0972-3099) Vol.13 (1\&2) (125-128), 2012.

Fish diversity of Chargaon Reservior, Distict Chandrapur (M. S.) India. Kamdi R.R., Sawane A. P. and Kale M.C. Indian Stream Research Journal ISSN 2230-7850,2013.

Monitoring water quality parameters from some freshwater wetlands of Warora Taluka, Chandrapur District,Maharashtra State. Khekare S.R. and Sawane A.P.

International Journal of Research in Bioscience, Agriculture and Technology. ISSN No online 2347-517x, Feb.-2015.

Zooplankton diversity in Kollar river, District Nagpur (M.S.) India Rawalekar K. 
N. \& Sawane A. P. International Journal of life sciences, special issue A6 P. 181-185 Feb.2016 ISSN. 2320-7817/e ISSN 2320964-x.

Ichthyofaunal diversity of Wardha River in the vicinity of Warora, Dist.-Chandrapur (M.S.), India.(2016);I.J.B.A.T. special issue 2016 : 136-139, Khekare S.S. and Sawane A.P.

Ali, A., M. N. Bhatti, N. Khan and Rehman M. N. 2006. Role of soil and water chemistry in aquaculture. Proceedingsof International conference on" Solving problems of Freshwater Fish Farming in Pakistan" November 27-28, 2006. UVAS. 139-141.

APHA-AWWA-WEF. 2005. Standard methods for the examination of water and wastewater, 20th edition. Washington DC, USA: American Public Health Association.

Bhatt, S.D., Y. Bisht and Negi U. 1984. Ecology of the limmofauna in the river Kosi of the Kumaun Himalaya. Proc.Indian Matn. Sci. Acid. 50:395-405.

Boyd, C. E., and Tucker, C. S.1998. Pond aquaculture and water quality management. Kluwer Academic Pub., London. Pp: 44-48.

Hayat, S., M. Javed and Hanif, K. 1996. Impact of poultry droppings fertilization of fish ponds on the physico-chemistry of water. Pakistan J. Live. Pollution. 2: 199208.

Jena, J. K., P. K. Arvindakshan, S. Chanra, H. K. Muduli and Ayyappan, S.
1998. Comparative evaluation of growth and survival of Indian major carps rearing fingerlings. J. Aquacult. Trop. 13: 143-149.

Jhingran., 1965. Report on inland fisheries research and management and fish culture in the U.S.S.R. Misc. contr. Cent. Int. Fish. Res. Inst, Barrackpore 5:27.

Tepe, Y., Turkmen A., Mutlu E. and Ates A. (2005). Some physico-chemical characteristic of Yarseli Lake, Hayat, Turkey. Tur. J. Fish. Aquacult. Sci. 5: 5342.

Upadhyay., 1997. Physico-chemical analysis of Kaliasote dam water to evaluate its versatile potentiality including irrigation use. Thesis of $\mathrm{Ph}$. D. (Chemistry) Barkatullah University Bhopal.

Welch, P. S., 1952. Mc Graw- Hill Book Co. NY, Toronto, London. Limnol. 538.

Odum E.P. 1971. Fundamental of Ecology 574pp, Philadelphia

Kumar, A.R. and P. Riyazuddin, 2006: Chemical Speciation of Trace metals in aquatic environment - An overview. Res. Chem. Environ. 10 (93-103)

Ali, S.S., 1999. Freshwater Fishery Biology. 1st Ed.. Naseem Book Depot, Hyderabad, Pakistan. pp: 10814 .

Rautela, K., K. Bisht, K.L. Joshi, V.D. Negi, K.S. Rautela and Dobriyal, A.K. 2006. Ecological studies on the biodiversity of river Khoh in the foot hills of Garhwal Himalaya, Part-2: Macrozoobenthic analysis. Aquacult. 7: 277-283.

Table. 1 Average monthly and seasonal variation in water temperature $\left({ }^{\circ} \mathrm{C}\right)$ of NavargaonLake (2016-2017)

\begin{tabular}{|c|c|c|c|c|c|c|c|c|c|c|c|c|}
\hline Month & Feb. & Mar. & Apr. & May. & Jun. & Jul. & Aug. & Sep. & Oct. & Nov. & Dec. & Jan. \\
\hline Spot A & 12.3 & 14.7 & 15.5 & 17.8 & 20.4 & 21.5 & 21.9 & 20.4 & 19.7 & 17.9 & 14.5 & 12.7 \\
\hline Spot B & 15.5 & 17.3 & 17.3 & 19.6 & 20.5 & 20.4 & 20.8 & 19.5 & 18.6 & 17.7 & 16.4 & 15.6 \\
\hline Spot C & 11.2 & 15.6 & 17.2 & 19.7 & 19.5 & 20.7 & 22.4 & 20.6 & 18.8 & 16.9 & 13.4 & 11.6 \\
\hline Spot D & 16.3 & 17.8 & 18.5 & 20.5 & 20.8 & 21.5 & 21.3 & 19.6 & 18.6 & 17.6 & 16.8 & 15.3 \\
\hline Spot E & 16.5 & 17.9 & 18.3 & 20.8 & 20.2 & 20.3 & 21.5 & 19.5 & 18.8 & 17.3 & 16.7 & 15.4 \\
\hline Average & 14.36 & 16.66 & 17.36 & 19.68 & 20.28 & 20.28 & 21.58 & 19.92 & 18.9 & 17.48 & 15.56 & 14.12 \\
\hline Season & & \multicolumn{2}{|c|}{ Spring } & \multicolumn{2}{|c|}{ Summer } & \multicolumn{2}{|c|}{ Monsoon } & \multicolumn{3}{|c|}{ Autumn } & \multicolumn{2}{|c|}{ Winter } \\
\hline
\end{tabular}

Table.2 Average monthly and seasonal variation in water current velocity $(\mathrm{m} / \mathrm{s})$ of Navargaon Lake.

\begin{tabular}{|c|c|c|c|c|c|c|c|c|c|c|c|c|}
\hline Month & Feb. & Mar. & Apr. & May. & Jun. & Jul. & Aug. & Sep. & Oct. & Nov. & Dec. & Jan. \\
\hline Spot A & 0.289 & 0.364 & 0.393 & 0.416 & 0.576 & 0.663 & 0.849 & 0.615 & 0.433 & 0.269 & 0.281 & 0.274 \\
\hline Spot B & 0.304 & 0.337 & 0.393 & 0.428 & 0.438 & 0.864 & 0.957 & 0.813 & 0.522 & 0.391 & 0.324 & 0.314 \\
\hline Spot C & 0.271 & 0.366 & 0.398 & 0.421 & 0.421 & 0.633 & 0.765 & 0.651 & 0.434 & 0.354 & 0.265 & 0.261 \\
\hline Spot D & 0.337 & 0.351 & 0.598 & 0.924 & 0.924 & 0.963 & 0.972 & 0.811 & 0.614 & 0.483 & 0.388 & 0.391 \\
\hline Spot E & 0.334 & 0.349 & 0.598 & 0.944 & 0.923 & 0.877 & 0.951 & 0.813 & 0.619 & 0.433 & 0.335 & 0.325 \\
\hline Average & 0.307 & 0.353 & 0.476 & 0.627 & 0.656 & 0.656 & 0.899 & 0.741 & 0.524 & 0.386 & 0.319 & 0.313 \\
\hline Season & \multicolumn{4}{|c|}{ Spring } & \multicolumn{1}{|c|}{ Summer } & \multicolumn{1}{|c|}{ Monsoon } & \multicolumn{4}{c|}{ Autumn } & \multicolumn{1}{c|}{ Winter } \\
\hline
\end{tabular}


Table.3 Average monthly and seasonal variation in turbidity(NTU) of NavargaonLake.

\begin{tabular}{|c|c|c|c|c|c|c|c|c|c|c|c|c|}
\hline Month & Feb. & Mar. & Apr. & May. & Jun. & Jul. & Aug. & Sep. & Oct. & Nov. & Dec. & Jan. \\
\hline Spot A & 09 & 11 & 17 & 10 & 12 & 95 & 86 & 51 & 31 & 11 & 08 & 10 \\
\hline Spot B & 06 & 05 & 11 & 09 & 17 & 91 & 96 & 64 & 41 & 18 & 07 & 10 \\
\hline Spot C & 05 & 08 & 09 & 11 & 22 & 88 & 99 & 59 & 39 & 14 & 05 & 07 \\
\hline Spot D & 07 & 09 & 06 & 13 & 21 & 89 & 94 & 61 & 31 & 12 & 11 & 08 \\
\hline Spot E & 09 & 07 & 05 & 09 & 19 & 94 & 97 & 57 & 27 & 10 & 09 & 08 \\
\hline Average & 7.2 & 8.0 & 9.6 & 10.4 & 18.2 & 91.4 & 94.4 & 58.4 & 33.8 & 13 & 8.0 & 8.6 \\
\hline Season & \multicolumn{10}{|c|}{ Spring } & \multicolumn{10}{|c|}{ Summer } & \multicolumn{10}{|c|}{ Monsoon } & \multicolumn{1}{c|}{ Autumn } & Winter \\
\hline
\end{tabular}

Table.4 Average monthly and seasonal variation in $\mathrm{pH}$ of NavargaonLake.

\begin{tabular}{|l|l|l|l|l|l|l|l|l|l|l|l|l|}
\hline Month & Feb. & Mar. & Apr. & May & Jun. & Jul. & Aug. & Sep. & Oct. & Nov. & Dec. & Jan. \\
\hline Spot A & 8.2 & 8.3 & 8.2 & 8.1 & 8.2 & 7.9 & 7.9 & 8.3 & 8.2 & 8.6 & 8.2 & 8.1 \\
\hline Spot B & 7.4 & 8.3 & 8.2 & 8.7 & 8.6 & 7.6 & 7.6 & 7.3 & 7.4 & 7.7 & 8.1 & 8.3 \\
\hline Spot C & 8.1 & 8.6 & 8.2 & 7.9 & 7.9 & 7.2 & 7.8 & 8.2 & 8.3 & 8.1 & 8.7 & 8.4 \\
\hline Spot D & 8.2 & 8.1 & 8.2 & 8.3 & 8.5 & 8.1 & 8.1 & 7.9 & 7.8 & 8.3 & 8.5 & 8.2 \\
\hline Spot E & 8.0 & 8.1 & 8.2 & 8.3 & 8.3 & 8.0 & 8.1 & 7.6 & 7.8 & 8.0 & 8.1 & 8.2 \\
\hline Average & 7.98 & 8.28 & 8.2 & 8.26 & 8.3 & 7.76 & 7.9 & 7.86 & 7.9 & 8.14 & 8.32 & 8.24 \\
\hline Season & \multicolumn{3}{|c|}{ Spring } & \multicolumn{8}{|c|}{ Summer } & \multicolumn{8}{|c|}{ Monsoon } & \multicolumn{5}{c|}{ Autumn } & Winter \\
\hline
\end{tabular}

Table.5 Average monthly and seasonal variation in dissolve oxygen $(\mathrm{mg} / \mathrm{l})$ of NavargaonLake.

\begin{tabular}{|l|l|l|l|l|l|l|l|l|l|l|l|l|}
\hline Month & Feb. & Mar & Apr. & May. & Jun. & Jul. & Aug. & Sep. & Oct. & Nov. & Dec. & Jan. \\
\hline Spot A & 9.1 & 8.9 & 8.4 & 8.6 & 7.8 & 7.2 & 8.1 & 8.5 & 9.3 & 9.8 & 10.5 & 10.3 \\
\hline Spot B & 8.3 & 8.9 & 7.8 & 7.2 & 7.4 & 7.4 & 7.1 & 8.6 & 9.3 & 10.1 & 10.4 & 10.8 \\
\hline Spot C & 9.2 & 8.9 & 9.5 & 8.3 & 7.9 & 8.2 & 8.7 & 8.7 & 9.4 & 9.2 & 10.9 & 10.1 \\
\hline Spot D & 8.4 & 9.3 & 8.7 & 7.4 & 7.4 & 8.2 & 8.3 & 9.3 & 9.9 & 10.5 & 11.1 & 10.9 \\
\hline Spot E & 8.4 & 9.3 & 8.6 & 7.9 & 7.5 & 7.9 & 8.2 & 9.5 & 9.8 & 10.5 & 10.7 & 11.2 \\
\hline Average & 8.68 & 9.06 & 8.6 & 7.88 & 7.6 & 7.78 & 8.08 & 8.92 & 9.54 & 10.02 & 10.72 & 10.66 \\
\hline Season & \multicolumn{8}{|c|}{ Spring } & \multicolumn{8}{|c|}{ Summer } & \multicolumn{8}{c|}{ Monsoon } & \multicolumn{6}{c|}{ Autumn } & Winter \\
\hline
\end{tabular}

Table.6 Average monthly and seasonal variation in Total alkalinity (mg/1) of Navargaon Lake.

\begin{tabular}{|c|c|c|c|c|c|c|c|c|c|c|c|c|}
\hline Month & Feb. & Mar. & Apr. & May. & Jun. & Jul. & Aug. & Sep. & Oct. & Nov. & Dec. & Jan. \\
\hline Spot A & 91.9 & 80.1 & 76.2 & 71.0 & 64.2 & 62.4 & 60.8 & 64.4 & 73.5 & 85.9 & 89.9 & 92.4 \\
\hline Spot B & 96.2 & 87.1 & 80.8 & 74.1 & 63 & 61.7 & 61.8 & 62.5 & 79.8 & 89.1 & 99.2 & 101 \\
\hline Spot C & 99.6 & 83.4 & 78.5 & 74.7 & 62.7 & 65.4 & 59.9 & 67.8 & 77.6 & 81.1 & 101.5 & 99.2 \\
\hline Spot D & 103.3 & 97.1 & 79.7 & 70.2 & 71.1 & 60.1 & 57.6 & 70.4 & 91.1 & 95.3 & 98.2 & 99.8 \\
\hline Spot E & 111.3 & 97.1 & 81.7 & 73.2 & 73.1 & 62.8 & 56.6 & 71.1 & 87.1 & 91.3 & 91.9 & 108.2 \\
\hline Average & 100.46 & 88.96 & 79.38 & 72.64 & 66.82 & 62.48 & 59.34 & 67.24 & 81.82 & 88.54 & 96.14 & $\begin{array}{c}100.1 \\
6\end{array}$ \\
\hline
\end{tabular}

Table.7 Average monthly and seasonal variation in total hardness (mg/L) of Navargaon Lake.

\begin{tabular}{|c|c|c|c|c|c|c|c|c|c|c|c|c|}
\hline Month & Feb. & Mar. & Apr. & May. & Jun. & Jul. & Aug. & Sep. & Oct. & Nov. & Dec. & Jan. \\
\hline Spot A & 101.2 & 93.7 & 91.2 & 89.1 & 75.4 & 77.5 & 78.2 & 77.2 & 82.5 & 90.6 & 92.3 & 97.5 \\
\hline Spot B & 109.3 & 98.8 & 85.9 & 78.2 & 77.1 & 75.9 & 74.9 & 78.2 & 82.1 & 89.2 & 96.7 & 101.2 \\
\hline Spot C & 104.3 & 98.5 & 99.8 & 92 & 90 & 84.4 & 81.7 & 84.9 & 89.6 & 98.4 & 99.6 & 103.1 \\
\hline Spot E & 119.1 & 107.4 & 96.2 & 86.3 & 84.6 & 79.9 & 84.3 & 86.9 & 87.5 & 98.2 & 106.3 & 108.5 \\
\hline Average & 109.26 & 98.98 & 93.56 & 86.62 & 82.44 & 78.52 & 80.3 & 83.08 & 86.64 & 95.56 & 100.2 & 103.9 \\
\hline
\end{tabular}


Table 8. Average monthly and seasonal variations in Macro-zoo benthic density (Units $/ \mathrm{m}^{2}$ )

\begin{tabular}{|c|c|c|c|c|c|c|c|c|c|c|c|c|}
\hline $\begin{array}{l}\text { Macrobenthic } \\
\text { groups } \\
\left(\text { Units } / \mathrm{m}^{2}\right)\end{array}$ & Feb. & Mar & Apr. & May. & Jun. & Jul. & Aug. & $\begin{array}{c}\text { Sep } \\
.\end{array}$ & Oct. & Nov. & Dec. & Jan. \\
\hline Ephemeroptera & 149 & 73 & 52 & 24 & 21 & 12 & 35 & 64 & 110 & 144 & 211 & 155 \\
\hline Trichoptera & 140 & 77 & 35 & 21 & 10 & 08 & 35 & 64 & 110 & 144 & 210 & 150 \\
\hline Diptera & 145 & 116 & 63 & 43 & 34 & 13 & 29 & 62 & 88 & 139 & 145 & 110 \\
\hline Plecoptera & 48 & 39 & 43 & 40 & 21 & 02 & 01 & 14 & 03 & 14 & 20 & 51 \\
\hline Coleoptera & 46 & 61 & 22 & 38 & 11 & 09 & 22 & 22 & 94 & 88 & 99 & 39 \\
\hline Odonata & 42 & 76 & 39 & 29 & 07 & 12 & 50 & 52 & 92 & 110 & 130 & 52 \\
\hline $\begin{array}{c}\text { Total Macro-zoo } \\
\text { benthos } \\
\left.\text { (Unit } / \mathrm{m}^{2}\right)\end{array}$ & 570 & 442 & 254 & 195 & 104 & 56 & 172 & 278 & 497 & 639 & 815 & 557 \\
\hline Season & & \multicolumn{2}{|c|}{ Spring } & \multicolumn{2}{|c|}{ Summer } & \multicolumn{2}{|c|}{ Monsoon } & \multicolumn{3}{|c|}{ Autumn } & \multicolumn{2}{|c|}{ Winter } \\
\hline
\end{tabular}

Table 9. Average monthly and seasonal variations of Plankton density (Units/L)

\begin{tabular}{|c|c|c|c|c|c|c|c|c|c|c|c|c|}
\hline $\begin{array}{c}\text { Plankton group } \\
\text { (Units/L) }\end{array}$ & Feb. & Mar. & Apr. & May. & Jun. & Jul. & Aug. & Sep. & Oct. & Nov. & Dec. & Jan. \\
\hline Chlorophyceae & 375 & 725 & 325 & 510 & 135 & 275 & Nil & 230 & 475 & 650 & 500 & 600 \\
\hline Cyanophyceae & 225 & 175 & Nil & 200 & 125 & 125 & Nil & 125 & 75 & 150 & 200 & 250 \\
\hline Total phytoplankton & 600 & 900 & 325 & 710 & 260 & 400 & Nil & 355 & 550 & 800 & 700 & 850 \\
\hline Crustaceans & 175 & 100 & 50 & 175 & 25 & 75 & 25 & 75 & 100 & 225 & 155 & 125 \\
\hline Rotifers & Nil & 100 & 200 & 220 & 75 & Nil & Nil & 25 & 25 & 175 & 100 & 60 \\
\hline Total Zooplankton & 175 & 200 & 250 & 395 & 100 & 75 & 25 & 100 & 125 & 400 & 215 & 185 \\
\hline $\begin{array}{c}\text { Total Plankton } \\
\text { (Units/L) }\end{array}$ & 2350 & 1925 & 1800 & 1815 & 1050 & 877 & 425 & 1180 & 2975 & 3029 & 2850 & 3110 \\
\hline Season & & \multicolumn{2}{|c|}{ Spring } & \multicolumn{2}{|c|}{ Summer } & \multicolumn{2}{|c|}{ Monsoon } & \multicolumn{3}{|c|}{ Autumn } & \multicolumn{2}{|c|}{ Winter } \\
\hline
\end{tabular}

